\title{
The Synods of the Diocese of Tarnów as a tool for the renewal of the particular Church
}

\begin{abstract}
This article analyses the last four synods of the diocese of Tarnów, highlighting their structure and course. Diocesan synods grow out of the needs of the particular Church; they shape the ecclesial reality most clearly by the formulated disciplinary, pastoral and spiritual proposals, reaching the very basic ecclesiastical and social environments. Each synod has its specific meaning in the history of the diocese, and its impact is certainly not limited to the formulated proposals. A diocesan synod has a very important function in the process of formation of the particular Church. The synods of the Diocese of Tarnów were the place of meeting of and dialogue between the bishop, the clergy and the laity of the Church in Tarnów. The present article discusses five points : "Legal grounds", "First Synod of the Diocese of Tarnów - 1928", "Second Synod of the Diocese of Tarnów 1938", "Third Synod of the Diocese of Tarnów - 1948”, "Fourth Synod of the Diocese of Tarnów - 1986”.
\end{abstract}

\section{Keywords}

Diocesan synods, Diocese of Tarnów, Particular Church.

Diocesan synods grow out of the needs of the particular Church; they shape the ecclesial reality most clearly by the formulated disciplinary, pastoral and spiritual proposals, reaching the very basic ecclesiastical and social environments. Each synod has its specific meaning in the history of the diocese, and its impact is certainly not limited to the formulated proposals. 
The diocese of Tarnów was established in 1786, on the territory of the southern part of the diocese of Cracow, located on the right side of the Vistula River. It was the second Polish diocese established by the partitioning authorities in the Polish territories occupied during the First Partition. Over the years, its boundaries have changed several times. The last change took place during the reorganisation of the dioceses and ecclesiastical provinces under John Paul II's Papal bull of 25 March 1992, entitled „TOTUS TUUS Poloniae Populus”.

The motive for writing this article was the convocation of the Fifth Synod of the Diocese of Tarnów by Bishop Andrzej Jeż. It seemed fitting to outline the history of the synodal assemblies in the diocese of Tarnów. This article, thus, analyses the previous four synods of the diocese of Tarnów, highlighting their structure and course.

\section{Legal grounds}

The Code of Canon Law, promulgated by Pope Benedict XV in 1917, devotes only six canons to the institution of diocesan synod. The Codification of 1917 collects the entire canonical tradition concerning the diocesan synod. This institution has its origins in the $4^{\text {th }}$ century. Diocesan synods were convened once or more times a year. In the $6^{\text {th }}$ century, the Synod of Auxerre ordered the diocesan clergy to gather once a year for deliberation. A universal ecclesiastical rule was established during the Fourth Council of the Lateran, which ordered the bishops to convene diocesan synods every year under the penalty of suspension. In turn, the Council of Trent reminded this rule and defined who was to attend. In Poland, in the first decades of the $13^{\text {th }}$ century, diocesan synods were convened twice a year, and later, once a year. The decree of the Council of Trent on the annual convening of the synod was not respected in its entirety. ${ }^{1}$

In the Code of Canon Law of 1917, a uniform, universal, ecclesiastical image of the institution was outlined for the first time in the history of the Church. The 1917 Code for the first time defines, although in a very general form, the functions of the diocesan synod. This is justified by Rev. Prof. Tomasz Rozkrut: ${ }^{2}$

${ }^{1}$ Cfr. F. Bączkowicz, Prawo kanoniczne. Podręcznik dla duchowieństwa, vol. I, Opole 1957, pp. 522-523.

2 T. Rozkrut, Synod diecezjalny w Kościele, Tarnów 2002, pp. 52-53. 
- the diocesan synod is to be celebrated every ten years to consider issues referring to the needs of the clergy and people of that diocese (can. 356);

- the diocesan synod is convoked by the bishop of the diocese who presides over the sessions in the cathedral (can. 357);

- the Code presents a very precise list of persons who are required to attend the diocesan synod - they are the participants by law. It further specifies whom the bishop may also call to participate in the synod; lay members of Christ's faithful have no right to participate in the sessions of the synod (can. 358);

- participation in the work of the synod is to be always personal and never by a procurator delegated for this purpose (can. $359 \$ 1$ );

- the diocesan synod is prepared by special committees appointed for this purpose (can. 360);

- all the proposed issues are discussed during the preliminary sessions of the synod (can. 361). The subject of the synodal discussion depends on the bishop. He may appoint one or more committees prior to the synod to prepare the subject for discussion. He is to strive to have the draft of the decrees delivered to the synod participants before the sessions. At the general sessions, final resolutions are passed;

- at the diocesan synod, the bishop of the diocese is the only legislator, the others having only an advisory role; synodal constitutions enter in vigore immediately after their promulgation (can. 362).

After the publication of the Code of 1917, there were dioceses where the synod was convened regularly every ten years, but most of dioceses convened it one or two times during that period. Only in the period immediately following the promulgation of the Code can we see a large number of diocesan synods which provided an opportunity for adaptation of the particular law to the new universal law, but not only; at that time, diocesan synods also considered papal teaching, liturgical arguments, preaching, music and sacred art and the apostolate of the laity. Also in the time after the promulgation of the 1917 Code, some diocesan synods were convened only in order to maintain the prescribed standard of the Code. ${ }^{3}$

3 T. Rozkrut, Synod diecezjalny w Kościele, Tarnów 2002, p. 54. 


\section{The First Synod of the Diocese of Tarnów - 1928}

The Code of Canon Law of 1917 states that a diocesan synod is to be held at least every ten years in each diocese to touch upon the issues of the clergy and the faithful (can. $323 \$ 1$, CCL 1917). Such a synod is to be convened by the bishop in a cathedral and only the bishop can preside over it (can. 357, CCL 1917). Simultaneously, the law designated the participants of the synod (can. 358, CCL 1917) and the course of its sessions. In accordance with these recommendations, the synodal movement began in Poland; it was so intense that as many as 14 diocesan synods took place over 19 years (1920-1939). This undoubtedly encouraged Bishop Leon Wałęga to take up a similar action. Speaking of the synod, Bishop Wałęga said: „I would compare the synod with Confirmation. Just as Confirmation strengthens a Christian in the faith and provides the fullness of the supernatural life, the Synod makes the diocese permanent and full in its existence. I admit that I had seen this deficiency from the beginning, but without feeling the power to carry out such a great undertaking, I always pushed that thought aside, and it is now, in my old age, that I have proceeded, mainly at the behest of Rome (...). Therefore, in the name of God, the first diocesan synod shall begin, and if God blesses us, it shall be a milestone in the history of our diocese". ${ }^{4}$

On 4 April 1927, Bishop Leon Wałęga announced the convening of the diocesan synod, and Rev. Władysław Mysor was appointed as its promoter. The bishop determined the goals of the Synod to be the reconciliation of the diocesan law, applicable in the diocese, with the new Code of Canon Law, and supplementing the diocesan law with new regulations. At the same time, the bishop appointed 8 synodal committees: ${ }^{5}$

1. The Codification and Legislative Commission, chaired by Rev. Stanisław Bulanda, was intended to edit the synodal resolutions into statutes, consistent with the law of the universal Church, taking into account the diocesan customs.

2. The Pastoral Ministry Commission within the Church, presided over by Rev. Tomasz Włoch, was to address the problems of parish preaching, catechetical teaching, problems of contemporary errors in the field

${ }^{4}$ Pierwszy Synod Diecezji Tarnowskiej 1928, Tarnów 1928, p. 22.

${ }^{5}$ B. Kumor, Diecezja tarnowska. Dzieje ustroju i organizacji 1786-1985, Cracow 1985, pp. 367. 
of faith and morals and the ways of counteracting them, the holy sacraments, Catholic press, fraternities and ecclesiastical associations, as well as missions and retreats.

3. The Pastoral Ministry Commission outside the Church, with Rev. Józef Lubelski as its head, was to discuss the forms of extra-ecclesiastical pastoral care, such as parish organisations and associations, forms of charitable actions, emigration issues, Catholic League, out-of-school youth associations as well as the issues of labour and professional organisations.

4. The Liturgical Commission, chaired by Rev. Kasper Mazur, dealt with the order of services in parishes, worship of the Eucharist, church decor, singing and church choirs, parish rituals, artistic structure of churches and chapels, arrangement of parish cemeteries and church-related services.

5. The Economic Commission, presided over by Rev. Roman Sitko, deliberated over the issues of management and inventory of church goods, various fees, Mass offerings, alienation of church goods, religious legacies and foundations as well as parish competition.

6. The School Commission, with Rev. Franciszek Walczyński as its leader, dealt with textbooks for teaching religion in schools of all kinds, prayer books, pastoral care for schoolchildren, various aspects of catechetical work and church organisations among the youth.

7. The Management and Administration Commission, presided over by Rev. Władysław Mysor, was to discuss the role and powers of the Dean, the Dean's visitation form and the structure of congregations within deaneries as well as the jurisdiction of the Deans' visitator. It also discussed the attitude of the parish priest to the vicar, catechist and patron.

8. The Organisational Commission, chaired by Rev. Władysław Mysor, dealt with the preparation and editing of letters, decrees and acts as well as the synod ceremonial, the technical conduct of the synod and printing its resolutions, materials and papers.

The sessions of synodal commissions were held from the 4 to 25 July 1927. The objective of those sessions was to get familiar with the contents of the papers prepared in advance and to adopt appropriate decisions and resolutions. The Codification and Legislative Commission held its meeting on 30 July after receiving materials from other committees. At the meeting, all proposals and 
resolutions were discussed and materials for the preparation of synodal statutes were distributed between the various commissions. ${ }^{6}$

Shortly thereafter, guidelines were published discussing the scope of work of individual commissions, the commissions regulations, as well as the dates of meetings and composition of the commissions. According to those regulations, Bishop Leon Wałęga appointed about 120 people in total, mainly from the diocesan clergy and some of the clergy from religious communities, for the preparatory sessions of the diocesan synod. The conclusions of the commissions were printed as "preparatory resolutions to the diocesan synod” (Tarnów 1927), and on 5 August 1927, they were sent for discussion in deanery congregations. The comments from such discussions were then sent to the promoter of the synod. ${ }^{7}$

By the decree of 20 June 1928, Bishop Wałega convened the first diocesan synod in the cathedral, which was to be held on 21-23 August 1928, ordered the appropriate prayers and services on this matter and established a number of offices „f for the preservation of order and efficiency of the synodal sessions." $\mathrm{He}$ appointed auxiliary Bishop Edward Komar to be his Deputy, Rev. Władysław Mysor to be the Promoter of the synod and Rev. Stanisław Bulanda to be the Deputy Promoter. The remaining synodal offices were occupied by the following persons: Rev. R. Sitko as the Secretary of the synod, Rev. M. Rec as the Notary and M. Rev. F. Walczyński, Rev. R. Sitko, Rev. A. Albin and Rev. F. Miklasiński as the Judges for complaints and reasons for absence. The Prefect of the hospices was Rev. J. Lubelski, the Master of Ceremonies - Rev. K. Mazur and the Curate of the Clergy - Rev. A. Wilczkiewicz. ${ }^{8}$

The following officials were called to the synod: the Cathedral Chapter in gremio, 22 Deans, 23 parish priests, 8 religious superiors, 2 priests-professors from the Catholic University of Lublin (Rev. J. Wiślicki) and John Casimir University of Lviv (Rev. P. Stach), 5 honorary curial advisors, 19 Vice-Deans, 42 members of synodal commissions, 22 vicars, 3 guests and others. A total of 151 priests, who represented $30.88 \%$ of priests in the diocese (459 priests as of 31 December

${ }^{6}$ B. Kumor, Diecezja tarnowska. Dzieje ustroju i organizacji 1786-1985, Cracow 1985, pp. 368.

7 B. Plewa, Pierwszy Synod Diecezji tarnowskiej. Etap przygotowawczy (4 kwietnia 192720 czerwca 1928), "Tarnowskie Studia Historyczne" (2014), vol. 3, pp. 125.

${ }^{8}$ B. Kumor, Diecezja tarnowska. Dzieje ustroju i organizacji 1786-1985, Cracow 1985, pp. 369. 
1928), were to take part in the synod. As many as 16 of the invited priests did not attend the synod. ${ }^{9}$

At the synod, synodal examiners, judges and consultors were elected. By a decree of 8 September 1928, Bishop Wałęga reorganised the deanery network throughout the diocese. During the synod, a total of 275 synodal statutes were enacted. The first part of the publication of the synodal statutes entitled „On the cultivation of the holy faith” (Polish: „O pielęgnowaniu wiary świętej”) consisted of 26 statutes. The second part, „On sanctions in the Church” (Polish: „O karności kościelnej”), contains 111 statutes, the third part, „On the service to God” (Polish: „O służbie Bożej”) - 78 statutes, and the fourth part, „On ecclesiastical property” (Polish: „O majątku kościelnym”) - 60 statutes. The synodal statutes printed in the same year were accompanied by 19 attachments: Standards for the proclamation of the Word of God (1), Instruction for the organisation of parish missions (2), St. Joseph Association of priests of the diocese of Tarnów (3), Pius X's appeal to the clergy (4), Association of mutual prayers for happy death (5), instructions on canonical visitation (6), Instruction on deanery congregations (7), instruction on Dean's visitation (8), instruction on school visitation (9), Temperance association (10), The rite of the First Holy Communion (11), Reservations (12), Decree on the First Holy Communion (13), Instruction on marriage (14), Outline of the agreement with persons providing church-related services (15), Order of services (16), Order of the exposition of the blessed Sacrament (17), Instruction on securing the property of emptied churches and presbyteries (18) and Model lease contract (19). The synodal ordinances became effective on 1 January $1929 .{ }^{10}$

\section{The Second Synod of the Diocese of Tarnów - 1938}

According to the instructions of canon law, diocesan synods were to take place every 10 years. The next diocesan synod was therefore supposed to be held in 1938. On 26-27 August 1936, the First Plenary Synod of Poland was held at Jasna Góra Monastery in Częstochowa under the leadership of legate a latere Cardinal F. Marmaggi. The synod was attended by ordinaries of all three rites,

9 B. Kumor, Diecezja tarnowska. Dzieje ustroju i organizacji 1786-1985, Cracow 1985, pp. 369.

${ }^{10}$ Cfr. Pierwszy Synod Diecezji Tarnowskiej 1928, Tarnów 1928, p. 30-65. 
delegates of theological faculties in Lublin, Cracow, Lviv, Vilnius and Warsaw, as well as delegates of cathedral chapters and senior religious superiors. The synod enacted 151 resolutions, mainly of a pastoral nature. The synodal ordinances became available in Tarnów as early as in September 1937 and were distributed among the diocesan clergy, although they were to become applicable in Poland not earlier than as of 16 June 1938.

This plenary synod became one of the main reasons for convening the Second Synod of the Diocese of Tarnów. On 25 March 1938, in a letter to the clergy, Bishop Lisowski reminded that the plenary synod was taking effect on 16 June 1938 and it was 10 years after the last diocesan synod. Therefore, he decided to convene the second diocesan synod at the beginning of July $1938 .{ }^{11}$

The motives for convening the Second Synod of the Diocese of Tarnów were as follows:

1. promulgation of plenary synod resolution,

2. adaptation of the diocesan law to that resolution,

3. satisfaction of the provisions of canon law concerning the organisation of diocesan synods every 10 years,

4. introduction of amendments, changes and additions to the resolutions of the first diocesan synod and detailed elaboration of part of synodal documents devoted to ecclesiastical property, with particular reference to the Act of 17 March 1932 on Church contributions. ${ }^{12}$

In order to prepare materials for the synod, Bishop Lisowski ordered printing of the resolutions of the plenary synod in Currenda, in early 1938. The idea was to ensure that the texts of the plenary synod, which were soon to be in force in the diocese, were well known to priests. The resolutions of that synod were to be the subject of debates of congregations in deaneries, which were to be accompanied by problems related to ecclesiastical inventories and ecclesiastical property. Conclusions from the deanery congregations were to be sent to the promoter of the synod in Tarnów by 15 May $1938 .{ }^{13}$

The sessions of synodal commissions proceeded smoothly and swiftly; therefore, on 26 June 1938, Bishop Lisowski decided to hold the synod on 4 and

${ }^{11}$ F. Lisowski, Pismo do wiernych, "Currenda” VI (1938), p. 97.

12 B. Plewa, Drugi Tarnowski Synod Diecezjalny. Zapomniane wydarzenie w historii Kościoła lokalnego, "Rocznik Tarnowski" (2014), no. 19, pp. 55.

13 B. Kumor, Diecezja tarnowska. Dzieje ustroju i organizacji 1786-1985, Cracow 1985, pp. 370. 
5 July 1938 in Tarnów (in the cathedral and in the auditory of the Seminary). On this occasion, Bishop Lisowski once again stressed that the synod was to deal with adapting the life of the diocese and the clergy to the provisions of the plenary synod. He also arranged appropriate liturgical services in the diocese and presented the synod celebration programme. On the first day (4 July), the programme envisaged the opening ceremony followed by the reading of the opening decrees, confession of faith by the participants, election of synodal examiners, parish consultors and judges. It was all in the cathedral. Then, the synodal session held at the seminary auditory dealt with the duties of the clergy and the order of services in the diocese. On the second day - 5 July - during the first session, financial matters and duties of the laity, according to the plenary synod, were discussed, and some major issues and conclusions, which had been submitted to the promoter in advance, were analysed. In the second session, Bishop Lisowski's closing speech and appropriate liturgical ceremonies, including a tribute to the Bishop, were planned. A total number of 276 statutes were enacted. The second synod consisted of four parts: I - „On the cultivation of the holy faith” (Polish: „O pielęgnowaniu wiary świętej”) (statutes 1-24); II - „On sanctions in the Church” (Polish: „O karności kościelnej”) (statutes 25-125); III - „On the service to God” (Polish: „O służbie Bożej”) (statutes 126-203); IV - „On ecclesiastical property” (Polish: „O majątku kościelnym”) (statutes 204-276). Unfortunately, the Statutes of the Second Synod of the Diocese of Tarnów were not published immediately. It was not until 2016 that a source edition was published, which presented the probable statutes of the 1938 synod. ${ }^{14}$

\section{The Third Synod of the Diocese of Tarnów - 1948}

On 27 November 1947, at the annual congregation of Deans, Bishop Jan Stępa announced the convocation of the Third Synod of the Diocese of Tarnów. On 2 February 1948, in the pastoral letter to the clergy, the Bishop of Tarnów decided that the purposes of the third diocesan synod were: ${ }^{15}$

1. the election of synodal judges, examiners and parish consultors,

${ }^{14}$ R. Kantor, Synod w przededniu wojny. II Synod Diecezji Tarnowskiej - historia i rekonstrukcja statutów, Tarnów 2016, p. 87-89.

15 B. Kumor, Diecezja tarnowska. Dzieje ustroju i organizacji 1786-1985, Cracow 1985, pp. 371. 
2. the demarcation of the new boundaries of deaneries and questioning the former ones,

3. matters of parish and diocesan liturgy,

4. issues of pastoral work in the Church.

In the same pastoral letter, Bishop Stępa appointed auxiliary Bishop Karol Pękala as a special delegate and spokesperson for the coordination of the sessions of individual synodal commissions. Rev. Stanisław Bulanda became the promoter of the synod, and Rev. Ignacy Dziedziak - his deputy. By virtue of the same pastoral letter, the following synodal commissions were formed: a legislative commission chaired by Rev. Stanisław Bulanda; an organisational commission chaired by Rev. Władysław Węgiel; a pastoral commission, which was composed of three subcommissions: a) a section of pastoral ministry within the Church with Rev. Julian Piskorz as its head, b) a section of pastoral ministry outside the Church chaired by Rev. Władysław Lesiak and c) a school section chaired by Rev. Walenty Chrobak; liturgical commission presided over by Rev. Jan Bochenek, as well as an administration and economic commission chaired by Rev. Ignacy Dziedziak. ${ }^{16}$

These synodal commissions worked very efficiently and therefore, on 4 May 1948, Bishop Jan Stępa convoked the Third Synod of the Diocese of Tarnów for 5-7 July 1948 in Tarnów, and arranged appropriate services in the diocese. In accordance with the law, the following persons were invited and took part in the synod: auxiliary Bishop Karol Pękala, vicar and general official Rev. Stanisław Bulanda, the cathedral chapter in gremio including 4 honorary canons (8 persons), all the Deans (24 priests), parish priests from Tarnów (2 priests), chosen representatives of deaneries (29 priests) and representatives of religious orders and congregations (10 persons). There were as many as 75 people in total. Bishop Stępa also appointed prelates and papal chamberlains (9 persons), university professors ( 5 persons) and seminary professors (13 persons), honorary curial advisors (5 persons), members of the curia (6 persons), representatives of diocesan institutions ( 8 persons), catechists and members of synodal commissions (17 persons), as well as vicars chosen from individual deaneries (28 persons) - a total of 160 priests, of whom 12 did not attend the synod. ${ }^{17}$

16 B. Kumor, Diecezja tarnowska. Dzieje ustroju i organizacji 1786-1985, Cracow 1985, pp. 372.

17 B. Kumor, Diecezja tarnowska. Dzieje ustroju i organizacji 1786-1985, Cracow 1985, pp. 373. 
On the day of the opening of the synod, 5 July 1948, Bishop Stępa stated that the synod had three main tasks to be implemented: ${ }^{18}$

1. to adjust the diocesan legislation to the current requirements,

2. to make an overview of diocesan forces and coordinate them in apostolic work,

3. to capture the essence of the modern apostolate.

The synod enacted 277 statutes in total, of which 25 concerned the issue of cultivation of the holy faith, 101 - sanctions in the Church, 78 - service to God and 73 - ecclesiastical property. The synod was partially published in 1949 and took effect soon thereafter. All the statutes were printed in 1957, edited by Rev. Jan Rzepa and Rev. Piotr Bednarczyk. ${ }^{19}$

\section{The Fourth Synod of the Diocese of Tarnów - 1986}

33 years after the last diocesan synod, Bishop Jerzy Ablewicz decided to convene the fourth diocesan synod. On 3 November 1980, at the congregation of Deans and Vice-Deans, the bishop announced the convocation of the synod, and on 8 May 1981, he issued a decree appointing the Main Commission of the Fourth Synod of the Diocese of Tarnów. Auxiliary Bishop Piotr Bednarczyk became the chairman and Rev. Piotr Gajda, the Diocesan Court official - his deputy. As many as 15 priests were appointed as members of the Main Commission and its secretariat was a college of four priests. As stated in the decree on the appointment of the Main Commission, its task was the „comprehensive and methodical preparation of materials for the Fourth Synod of the Diocese of Tarnów in the pastoral and legal aspects as well as management of the synodal sessions. Also, its aim was not only to reach out to all the communities of the people of God in our diocese, but also to develop synodal schemes through the synodal committees and watch over the course of work and preparation of the final version of the text of the synodal statutes". ${ }^{20}$

18 B. Kumor, Diecezja tarnowska. Dzieje ustroju i organizacji 1786-1985, Cracow 1985, pp. 373.

19 B. Kumor, Diecezja tarnowska. Dzieje ustroju i organizacji 1786-1985, Cracow 1985, pp. 373.

20 J. Ablewicz, “Currenda” (1981), pp. 222-223. 
The preparatory work proceeded so smoothly that on 16 October 1981, Bishop Ablewicz approved and promulgated the „Statute of the Fourth Synod of the Diocese of Tarnów." According to that statute, the purpose of the Synod was ,to take joint action in order to deepen the faith and revive religious life in the diocese of Tarnów, based on the teachings of the universal Church, especially those given by the Second Vatican Council and the magisterium of the Church in the post-conciliar period". ${ }^{21}$ This general purpose of the synod was set out in the statute in great detail; therefore, the specific objectives of the synod were as follows: ${ }^{22}$

1. becoming aware of changes in the religious and moral reality taking place at that time in the diocese,

2. raising the awareness of the dangers and shortcomings within the doctrine and customs that were threatening the faithful at that time,

3. setting out the way out of the difficulties recognised concerning the pastoral work and administration of the diocese,

4. identifying modern methods of pastoral work wherever necessary,

5. thorough analysis and adaptation of the standards of the universal ecclesiastical law to the conditions existing at that time in the diocese,

6. improvement of the existing diocesan institutions and creation of new ones, if necessary.

The statute of the synod introduced a radical change concerning the participants; „all the people of God of the diocese of Tarnów shall attend the synod," in particular:

1. representatives of clergy from the diocese and religious communities as well as representatives of nuns working in the diocese, on the basis of nomination or special invitation of the Ordinary,

2. lay representatives, nominated or invited to cooperation in synodal institutions,

3. all other people from the diocese, clergymen and nuns as well as lay Catholics, through participation in various synodal discussions and presentation of their postulates to the secretariat. This time, priests who were university professors from the diocese were not invited.

${ }^{21}$ J. Ablewicz, “Currenda” (1981), pp. 223-224.

22 B. Kumor, Diecezja tarnowska. Dzieje ustroju i organizacji 1786-1985, Cracow 1985, pp. 375. 
By a decree of 16 October 1981, Bishop Ablewicz announced the Regulations of the Fourth Synod of the Diocese of Tarnów, by which he approved the problem commissions and their heads as prepared by the Main Commission. Ten such commissions were appointed: 1 . Theological Commission - Rev. K. Kupiec; 2. Teaching Commission with three subcommissions (concerning the preaching the word of God, catechesis and the media) - Rev. E. Lazarowicz; 3. Commission for the Worship of God with four subcommissions (concerning the liturgy, sacred art and church architecture, pastoral ministry and altar service) Rev. B. Margański; 4. Commission for Vocations and the Seminary with three subcommissions (concerning the vocations, seminary preparation for the priesthood and the material and economic matters of the Seminary) - Rev. S. Rosa; 5. Commission for the Lay Apostolate - Rev. M. Bednarz; 6. Pastoral Ministry Commission with five subcommissions (concerning youth ministry, marriage and family ministry, pastoral care for labour and professional groups, charity, sober and special ministry as well as missionary and ecumenical ministry) Rev. T. Szarwark; 7. Diocesan Clergy Commission with four subcommissions (for the intellectual formation, spiritual formation, pastoral office and living issues) - Rev. K. Kos; 8. Commission for Religious Orders - Fr. S. Podgórski, C.Ss.R.; 9. Diocesan Structures Commission - Rev. J. Dudziak; 10. Economic and Financial Commission - Rev. E. Krężel. ${ }^{23}$

On 11 February 1982, Bishop Jerzy Ablewicz issued a pastoral letter announcing the Fourth Synod of the Diocese of Tarnów. As the synod motto, he put forth the words „In the image of the universal Church” (Lumen gentium 23). The aim of the Fourth Synod of the Diocese of Tarnów was to deepen the awareness of the faithful about the particular Church. This task was accomplished, inter alia, through synodal Sundays, informative synodal sessions as well as due to personal involvement of the lay faithful, clergy and consecrated persons in the synodal sessions. The synod lasted for several years and led to the elaboration of new diocesan law from scratch. This new law was contained in 747 statutes, 12 instructions and 7 statutes of ecclesiastical institutions. ${ }^{24}$

${ }^{23}$ B. Olejnik, Analiza historyczno-prawna struktury i organizacji IV Synodu Diecezji Tarnowskiej w trzydziestolecie zakończenia, Tarnów 2016, p. 51-68.

${ }^{24}$ List biskupa tarnowskiego Jerzego Ablewicza zapowiadający Czwarty Synod Diecezji Tarnowskiej z dnia 11 lutego 1982 r., "Currenda," 5-6 (1982), pp. 99. 
The Instruction entitled Ecclesiae imago reads: „In order for a synod to be properly organised and to truly contribute to the development of the community, it must be carefully prepared, both through the proper arrangement of its content, as well as through the mobilisation of public opinion and the awareness of the faithful, which is achieved by proper dissemination of the news concerning the Synod" (Ecclesiae imago, 164). Therefore, in order to prepare the Fifth Synod of the Diocese of Tarnów, the Bishop of Tarnów appointed the Preparatory Commission, following the Instruction of 19 March 1997 entitled De Synodis Dioecesanis Agendis (III.B.1). The task of the Commission was to prepare the synodal sessions proper, develop pastoral assistance to the faithful in relation to the synod, develop the Synodal Regulations, hymn and logo, and to identify the issues to be the subject of the discussions. The mission of the Preparatory Commission will end on founding the Main Synodal Commission during the Inauguration ceremony. ${ }^{25}$

Today it cannot be denied that the history of the Church, and the political as well as the cultural history of the Western World and Byzantium, cannot be understood without knowing the history of the ecumenical councils. Conciliar events are the milestones in the two millennia that have passed since the birth of Christ. Those unique events were shaped by the, so-called, Council of Jerusalem described in the Acts of the Apostles. A conciliar event is generally a deep reflection on the doctrinal problems and practices that the Church should take into account in its mission. A role analogous to the ecumenical councils, is played by plenary, provincial and diocesan synods on a regional and local level.

A diocesan synod has a very important function in the process of formation of the particular Church. The synods of the Diocese of Tarnów were the space of meeting and dialogue between the bishop, the clergy and the laity of the Church in Tarnów.

\section{Bibliography}

Ablewicz J., List biskupa tarnowskiego Jerzego Ablewicza zapowiadający Czwarty Synod Diecezji Tarnowskiej z dnia 11 lutego 1982 r., „Currenda” 5-6 (1982), pp. 98-101.

Bączkowicz F., Prawo kanoniczne. Podręcznik dla duchowieństwa, vol. I, Opole 1957.

25 A. Jeż, Komisja Przygotowawcza V Synodu Diecezji Tarnowskiej, "Currenda” 4 (2016), pp. 506-507. 
Codex Iuris Canonici 1917.

Codex Iuris Canonici 1983.

Jeż A., Komisja Przygotowawcza V Synodu Diecezji Tarnowskiej, „Currenda” 4 (2016), pp. 506-507.

Kantor R., Synod w przededniu wojny. II Synod Diecezji Tarnowskiej-historia i rekonstrukcja statutów, Tarnów 2016.

Kumor B., Diecezja tarnowska. Dzieje ustroju i organizacji 1786-1985, Cracow 1985.

Olejnik B., Analiza historyczno-prawna struktury i organizacji IV Synodu Diecezji Tarnowskiej w trzydziestolecie zakończenia, Tarnów 2016.

Pierwszy Synod Diecezji Tarnowskiej 1928, Tarnów 1928.

Plewa B., Drugi Tarnowski Synod Diecezjalny. Zapomniane wydarzenie w historii Kościoła lokalnego, „Rocznik Tarnowski” (2014) no. 19, pp. 53-59.

Plewa B., Pierwszy Synod Diecezji tarnowskiej. Etap przygotowawczy (4 kwietnia 1927-20 czerwca 1928), „Tarnowskie Studia Historyczne” (2014), vol. 3, pp. 122-134.

Rozkrut, T., Synod diecezjalny w Kościele, Tarnów 2002, pp. 52-53.

Trzeci Synod Diecezji Tarnowskiej 1948, Tarnów 1957. 